\title{
Thiamine deficiency after feeding pyrithiamine
}

It is a well-known fact that thiamine pyrophosphate (TPP) clisappears rapidly from the tissues when a thiamine deficiency is incluced by withholding the vitamin from the diet ${ }^{1,2}$. Wooldey, however, calling forth severe symptoms of deficiency by feeding the antimetabolite pyrithiamine to mice on a diet with adequate amounts of thiamine, saw no decrease of TPP in the livers of these animals as compared to controls receiving thiamine only ${ }^{3}$. This led him to suggest that the development of clinical symptoms attributed to thiamine deficiency is not necessarily a result of a diminished TPP content of the tissues ${ }^{4}$. This would mean that a deficiency provoked by deprivation of thiamine is of a different nature as compared to that, elicited by feeding the analogue.

To investigate this point, similar experiments have been carried out in this laboratory using pigeons as test animals and oxythiamine as antagonist $t^{5}$. A significant decrease of TPP in heart and breast muscles was found, but only a slight reduction in liver and cerebrum.

As we now have some pyrithiamine at our disposal ${ }^{\star}$ the last experiment has been repeated, using this antimetabolite which is reputedly a more specific antagonist than oxythiamine ${ }^{6}$.

18 pigeons received daily by forced feeding: $2 \mathrm{~g}$ casein, $\mathrm{I} 8 \mathrm{~g}$ glucose, salt and vitamin mixtures ${ }^{1}$, water ad libidum and roo $\gamma$ thiamine (T). Io of these animals also received $623 \gamma$ pyrithiamine bromide hydrobromide ( $P$ T), making the molar ratio of $T$ to $P T=I: 5$ (Group B). The remaining 8 animals served as controls (Group A).

5 animals in group $B$ had to be sacrificed after I I to I6 days because they had developed severe symptoms of deficiency (opisthotonus, postural disturbances, inability to stand). Their average survival time was $\mathrm{r}_{4}$ days. The remaining pigeons of group $\mathrm{B}$ still showed no symptoms after 23 days and were then killed. The controls were sacrificed after r 9 days in the mean, except for one animal that had died from an unknown cause and was excluded from the experiment.

TPP was determined manometrically in extracts of breast muscle (pectoralis major), liver (not perfused), heart muscle, brain and kidneys. The TPP values found in the tissues of all pigeons of group $\mathrm{B}$ were combined as no difference was found between the animals with shorter and longer survival time. The results are given in Table I.

\section{TABLE I}

THIAMINE PYROPHOSPHATE CONTENT ( $\gamma / \mathrm{g}$ fresh tissue) OF SOME TISSUES OF PIGEONS RECEIVING THIAMINE AND PYRITHIAMINE OR THIAMINE ONLY

Group A: 7 pigeons, Ioo $\gamma$ thiamine daily, average survival time 19 days.

Group B: Io pigeons, Ioo $\gamma$ thiamine $+623 \gamma$ pyrithiamine daily, average survival time I9 days.

\begin{tabular}{|c|c|c|c|c|}
\hline \multirow[t]{2}{*}{ Tissue } & \multicolumn{2}{|c|}{$\begin{array}{c}A \\
-P T\end{array}$} & \multicolumn{2}{|c|}{$\begin{aligned} & B \\
+ & P T\end{aligned}$} \\
\hline & average & range & average & range \\
\hline Brain & $2.6 \mathrm{I} \pm 0.12$ & $2.39-3.27$ & $0.7^{8} \pm 0.03$ & $0.69-0.97$ \\
\hline Liver & $3.54 \pm 0.26$ & $2.77-4.63$ & $1.09 \pm 0.12$ & $0.67-0.95$ \\
\hline Heart muscle & $4.55 \pm 0.33$ & $3.83-5 \cdot 72$ & $1.00 \pm 0.06$ & $0.7^{2-1.29}$ \\
\hline Breast muscle & $4.42 \pm 0.27$ & $3 \cdot 60-5 \cdot 34$ & $1.80 \pm 0.08$ & $1.5^{\mathrm{I}-2.19}$ \\
\hline Kidneys & $4.36 \pm 0.19$ & $3.64-4.92$ & $2.08 \pm 0.10$ & I. $.77-2.92$ \\
\hline
\end{tabular}

It appears from these figures that feeding pyrithiamine does result in a highly significant decrease of TPP in all tissues examined.

It is known that pyrithiamine pyrophosphate (PTPP), in contrast to PT, inhibits the resynthesis of carboxylase from TPP and yeast apocarboxylase ${ }^{3,9}$. So it might be possible that the TPP values found in the animals of group $B$ were too low owing to a formation of PTPP in vivo. To check this possibility small amounts (0.05 or o.I $\gamma$ ) of TPP were added to some extracts whereupon the determination was again performed. The recovery of excess TPP was the same, whether added to extracts of deficient or normal tissues. So the low values found in the deficient animals as compared to the controls are not due to presence of the inhibitory PTPP in the extracts.

* We are greatly indebted to Dr. K. Folkers of Merck Inc. Rahway, N.J., for kindly giving us a sample of pyrithiamine. 
In a number of cases the activity of pyruvic decarboxylase in breast muscle was altion measured, in the same manner as described by MoNFOORT2. The effect of adring TPP was studicil simultaneously. The results are given in Table II. As may be seen, the activity of pyruric llecarboxylase is markedly reduced after feeding pyrithiamine. It can almost completely be restorol by adding TPP to the homogenates.

\section{TABLE II}

ANAEROBIC FORMATION OF $\mathrm{CO}_{2}$ IN PIGEON BREAST MUSClE HOMOGENATES

Each Warburg flask contained $200 \mathrm{mg}$ breast muscle, homogenized in $0.1 M$ phosphate buffer $\mathrm{pH}$ 6.2, containing o.oor $M$ magnesiumchloride and made up to a volume of $2.0 \mathrm{ml} .20 \mu \mathrm{MLO}$ sodium pyruvate were added after temp. equilibrium. Temperature: $37^{\circ} \mathrm{C}$. Gas phase: nitrogen.

\begin{tabular}{|c|c|c|c|c|c|}
\hline \multirow{2}{*}{ Group } & \multirow{2}{*}{$\begin{array}{c}\text { Number of } \\
\text { animals }\end{array}$} & \multirow{2}{*}{$P T$} & \multirow{2}{*}{$\begin{array}{l}\text { Arerage surt: } \\
\text { time }\end{array}$} & \multicolumn{2}{|c|}{$\mu$ Mol CO, in tho hours } \\
\hline & & & & $-T P P$ & -E $I O \because T P P$ \\
\hline A & 4 & - & I $9 \mathrm{~d}$ & $5.1 \pm 0.6$ & $6.1 \pm 0.7$ \\
\hline $\mathrm{B}$ & 4 & + . & $\mathrm{I} 9 \mathrm{~d}$ & $2.6 \pm 0.2$ & $5.5+0.2$ \\
\hline
\end{tabular}

These experiments show that the disappearance of TPP from the tissues and the behaviour of the pyruvic decarboxylase after feeding pyrithiamine run a course, closely parallel to that observed in a thiamine deficiency induced by omitting the vitamin from the diet, 10. As yet there seems to be no occasion for presuming that the deficiencies brought about in these two manners are indeed different from one another.

This work forms part of investigations on the metabolism and physiological function of thiamine by H. G. K. Westenbrink and collaborators.
Laboratory for Physiological Chemistry, The University, Utrecht (The Netherlands)
J. C. Koedam
E. P. Steyn-Parvé
D. L. Van RheEnen

1 M. Gruber, Biochim. Biophys. Acta, io (1953) I36.

2 C. H. Monfoort, Biochim. Biophys. Acta, I6 (1955) 2 I9.

3 D. W. Woolley, J. Biol. Chem., I9I (195I) 43 .

4 D. W. Woolley and R. B. Merrifield, Bull. Soc. Chim. Biol., 36 (I954) 1207.

5 E. P. Steyn-Parvé, Biochim. Biophys. Acta, I 4 (I954) 440.

B L. R. Cerecedo, M. Soodak and A. J. Eusebi, J. Biol. Chem., i89 (I95I) 293 ;

A. J. Eusebi and L. R. Cerecedo, Science, ilo (ig49) i62.

7 B. C. P. Jansen and H. G. K. Westenbrink, Acta Brevia Neerl., 3 (I933) 9.

8 H. G. K. WEStenbrink and E. P. Steyn-Parvé, Int. Rev. Vitamin Res., 2 I (I950) $46 \mathrm{I}$.

- S. EICH ANd L. R. Cerecedo, J. Biol. Chem., 207 (I954) 295.

${ }^{10}$ C. H. Monfoort, Biochim. Biophys. Acta, 8 (1952) 389.

Received October $13^{\text {th, }}$ 1955

\section{Intracellular distribution of vitamin $K$ in beef liver}

An analysis of the intracellular distribution of vitamin $K$ seemed of interest especially in view of the recent evidence that the vitamin is involved in oxidative phosphorylation (MARTIUS AND Nitz-Lirzow ${ }^{1}$ ). Data on the distribution of the vitamin in liver are presented in this note.

$90 \mathrm{~g}$ of beef liver were divided into portions and homogenized in a Waring blendor for I $5-30$ sec. The blended liver was centrifuged by the method of SchNeIDER AND HoOgEBOOM ${ }^{2}$ except that after separation of the mitochondria the remaining supernatant (containing the submicroscopic particles $(P)$ and the soluble $(S)$ fraction) was not further separated. Janus green staining indicated few mitochondria in the supernatant. The three fractions - nuclei $(N)$, mitochondria $(M)$, and supernatant $(P-S)$ - were lyophilized. Nitrogen was determined by the method of Dumas ${ }^{3}$. Attempts to identify the vitamin in the lyophilized nuclear fraction by paper chromatography (GREEN AND DAM${ }^{4}$ ) of a petroleum ether-ethanol extract and by its reaction (GREEN AND $\mathrm{DAM}^{5}$ ) with aluminium oxide were not successful. The fractions were therefore examined 